\title{
RADICAI TPACIFR
}

A SOCIALIST, FEMINIST, AND ANTI-RACIST JOURNAL ON THE THEORY AND PRACTICE OF TEACHING

Review

The $A B C$ s of Socialism by Bhaskar Sunkara

Reviewed by Adam Szetela

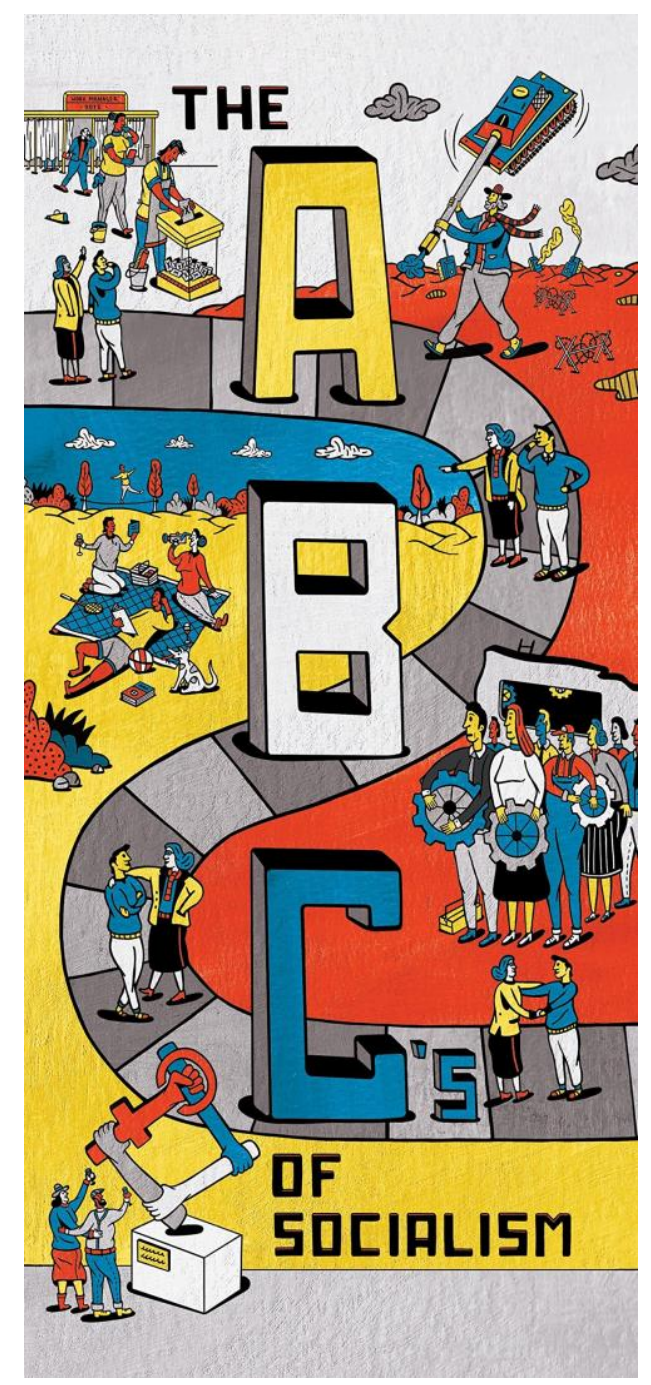

THE ABCS OF SOCIALISM BY BHASKAR SUNKARA. ILLUSTRATED BY PHIL WRIGGLESWORTH (VERSO, 2016) 


\section{The ABCs of Socialism by Bhaskar \\ Sunkara. Illustrated by Phil \\ Wrigglesworth (Verso, 2016)}

REVIEWED BY ADAM SZETELA

In 2010, Bhaskar Sunkara started the socialist magazine Jacobin, while he was an undergraduate at George Washington University. Since then, it has evolved into an international force with millions of readers, hundreds of reading groups, and an MVP-list of writers and supporters, who range from Noam Chomsky and the late Ellen Meiksins Wood to Dave Zirin and Chris Mathews. Jacobin's emergence has also spawned a flood of email messages from people around the world who are asking questions about socialism. In response, Sunkara recruited some of the leading voices on the left to write an introductory book. The result is The ABC's of Socialism.

The organization of the book is especially useful from a pedagogical standpoint. Each chapter is titled as a question - "Why do socialists talk so much about workers?" "Aren't socialism and feminism sometimes in conflict?" "Isn't America already kind of socialist?" - and the response to the question is written by a different scholar. From Keeanga-Yamahtta Taylor to Erik Olin Wright, the authors selected are noted radical intellectuals. They are also figures with track records writing not just for peerreviewed publications and academic presses, but venues such as The Nation, The New York Times, and Socialist Worker. Consequently, the book is accessible and free of obscure neologisms and flamboyant rhetorical gestures. Moreover, while many of Jacobin's articles are written as polemics for readers already sympathetic to socialist ideas, $A B C$ 's is written in a tone that invites uninitiated readers to think about capitalism and socialism in nuanced and critical ways. Most notably, the book recognizes the redeemable aspects of capitalism as well as the intersections between these economic systems and forms of social oppression such as racism and sexism.

For those of us who teach about socialism, this text is particularly useful, and there are a few different ways that I have incorporated the book into my undergraduate courses. First, I have assigned chapters to groups to present on during my unit on socialism. I listen to their presentations, and I fill in the blanks when they finish. Second, I have had students use their journals to reflect on a question, such as "Don't the rich deserve to keep all their money?", which is the title of chapter three, before we read the chapter. More often than not, the chapter and the ensuing discussion push students to reflect on their takenfor-granted axioms of capitalism in novel and more intellectually rigorous ways. For example, I have had more than one student recognize that the wealth of a company is a social product and not exclusively a product of individual genius and the "entrepreneurial spirit." Indeed, many of the questions in this book - "But at least capitalism is free and democratic, right?" - rebuke much of what passes as accepted political and economic orthodoxy in capitalist countries.

Even if this book were not used in a course, I think it would be of pedagogical benefit for radical teachers to read. At one level, it gives thorough responses to some of the most asked questions about socialism, which any teacher who teaches radical political and economic material will surely encounter. These questions range from inquiries about the role of individual rights in a socialist society to the perennial fear that, in the absence of the profit motive, socialism will stifle innovation. In addition, the accessibility of the text will show many educators, especially those in the jargon-filled world of academia, how to express these core concepts in simple ways, without sacrificing intellectual rigor. As someone who has observed other radical professors teach, I am always astounded by how teachers overcomplicate concepts, like "primitive accumulation" and "surplus value," for their students. The simple definitional explanations in $A B C^{\prime} s$ - such as the distinction between "private property" and "personal property," or "positive freedom" and "negative freedom" will give radical teachers a useful vocabulary to help them elaborate ideas central to socialism, in ways that are meaningful to younger people, and accessible enough for these students to retain and to use in future conversations.

Though I teach at Berklee College of Music where my students are more open-minded and progressive, not every book I have used has been well received. $A B C$ 's, however, has always been a hit. When I ask my students to reflect on the unit that I construct around this text, typical responses include "I had no idea capitalism was this undemocratic" and "I learned that the Soviet Union was not a socialist state." This latter comment speaks to one of the highest values of $A B C^{\prime} s$, which is its ability to deconstruct the popular "evil empire" image of socialism that still lingers in America's political imagination. As movements like Occupy Wall Street and the Sanders campaign linger in the background, with hopes of reemerging as political forces in the future, the distinctions between socialism today and "socialism" in the past will be as important as ever. For these reasons and others, I recommend The $A B C$ 's of Socialism without reservation to other radical teachers. (c)) BY-NC-ND

ULIS D-Sorle
This work is licensed under a Creative Commons Attribution-Noncommercial-No Derivative Works 3.0 United States License.

This journal is published by the University Library System of the University of Pittsburgh as part of its D-Scribe Digital Publishing Program, and is cosponsored by the University of Pittsburgh Press. 